\title{
INTERNATIONAL ROLES OF FOREIGN-OWNED SUBSIDIARIES IN NEW ZEALAND: AN EXPLORATORY STUDY
}

\author{
MUHAMMAD MUSTAFA RAZIQ \\ Massey University, Palmerston North, New Zealand \\ m.m.raziq@massey.ac.nz \\ MARTIN PERRY* and MARTINA BATTISTI ${ }^{\dagger}$ \\ Massey University, Wellington, New Zealand \\ *m.perry@massey.ac.nz \\ ${ }^{\dagger}$ m.battisti@massey.ac.nz
}

\begin{abstract}
Advances in the capacity to manage overseas operations have been linked to foreignowned subsidiaries of multinational enterprises performing more varied roles for their parent organisations than they did in the past. Drawing on evidence from an original largescale survey, this study explores the international roles performed by 429 foreign-owned subsidiaries in New Zealand. Traditionally, subsidiaries in New Zealand have predominantly been established to service the local market which although comparatively small is remote from major sources of foreign investment. The study finds that many subsidiaries have some form of international role and that subsidiaries frequently perform a variety of roles for their organisations. Investigation of subsidiary characteristics associated with an international role finds that those managed independently, and those managed by a network of reporting channels have most propensity and potential to engage in international roles. This evidence justifies greater recognition that subsidiary operations may make multiple contributions to their organisation rather than have a single purpose.
\end{abstract}

Keywords: Subsidiary international roles; subsidiary global initiative; exports; MNE management structures.

\section{Introduction}

It is now frequently claimed that the overseas subsidiaries of multinational enterprises (MNEs) are best understood as operating within networks of control and influence rather than being contained within a tightly specified managerial 
hierarchy (Andersson and Forsgren, 1996; Andersson et al., 2007). The consequence of this evolution in subsidiary management remains an area of debate. One proposition is that the growing scale of MNEs combined with an increased capacity to coordinate subsidiary operations is seeing the emergence of "performance plants" that are allocated regional or even world product mandates by their parent company (Pike, 1998; Pike et al., 2007). Such a claim implies that subsidiary operations remain potentially important units of analysis according to the roles that they are allocated. In contrast, an alternative proposition argues that subsidiaries are ceasing to be significant entities in their own right and in this sense they have become something of an "endangered species" - according to this

view, subsidiary operations have been dissected into individual value-adding functions (such as logistics, sales, manufacturing, research and development) each of which has its own reporting lines and operational ties (Birkinshaw and Pedersen, 2010). With the dilution of responsibility held by national country managers in favour of managing international operations through global business units, the operational coherence of subsidiaries has diminished. Rather than individual sites gaining broad responsibilities, the organisational capacity of MNEs is encouraging them to pursue corporate strategies by combining the resources of multiple locations.

Against these expectations of significant change in the management of subsidiary operations, this paper investigates the international roles performed by a large sample of (429) foreign-owned subsidiaries located in New Zealand and whether these roles can be related to subsidiary characteristics. The subsidiaries of foreign-owned companies in New Zealand have typically been thought to act mainly as marketing outposts to distribute goods and services developed elsewhere (KPMG, 1995; Scott-Kennel, 2001). This limited mandate may have contributed to a view that New Zealand's subsidiaries are comparatively simple operations existing with truncated responsibilities. For example, with the possible addition of some final processing and market customisation New Zealand based subsidiaries operate typically with few ties other than those to their parent company (ScottKennel, 2007). The main purpose of the present investigation is to determine whether this assessment has been superseded with subsidiaries now performing more diverse roles for their parent organisation. Evidence of this occurring would be significant for two reasons.

First, it would be significant confirmation of the evolution in subsidiary control where this can be shown to have affected subsidiaries that have previously been comparatively unconnected from a larger corporate endeavour. Second, where overseas ownership is associated with increasing operational freedom and development opportunity beyond a narrow responsibility for servicing the local market, there is a stronger case for supporting foreign investment than where foreignowned subsidiaries mainly service the local market. The OECD has claimed that 
administrative controls on foreign investment have tightened over the last decade (OECD, 2009, 2011). This change affects the potential grounds on which foreign investment might be challenged by the government's Overseas Investment Office (which reviews and decides on inward FDI applications for New Zealand). The practical extent of the change is minor but it does reflect longstanding anxiety that foreign owners are focused on transferring profits overseas rather than facilitating subsidiary development for the wider benefit of the local economy (Raziq and Perry, 2012a; Rosenberg, 1998). As well as the ability to comment on these issues the study explores whether the forms of subsidiary control and behaviour observed in New Zealand are more consistent with the possibility of selective upgrading to the status of a performance plant or the fragmentation of subsidiary power across inter connected locations.

The paper explores the development and evolution of foreign-owned subsidiaries in New Zealand by taking their international roles as determinants of their development. The internationalisation-developmental perspective taken here builds on the argument that the internationalisation process of the firms is followed by the developmental process of the firms as firms increasingly involve and commit resources to subsidiaries in overseas markets (Birkinshaw and Hood, 1997; Johanson and Vahlne, 1977). This perspective identifies three actors as having influence over the development of overseas subsidiaries: subsidiary itself, the parent MNE, and the subsidiary local environment, (Birkinshaw and Hood, 1997). In this view of subsidiary development, entrepreneurial initiatives taken by the overseas subsidiaries are seen to be the primary drivers of subsidiary development (Birkinshaw, 1997).

The paper proceeds by first providing a brief summary of literature about subsidiary roles, with a special emphasis on international roles and global initiatives of subsidiaries. This is followed by a brief literature on subsidiaries in New Zealand. The design of the survey that provides the original data analysed in the paper is then discussed followed by an outline of the principal findings and their implications.

\section{Subsidiary Roles}

Generally a subsidiary may be allocated one of the three primary roles: local implementer, specialized contributor, and world mandate (Table 1). Local implementers largely focus on the local market and have high operational autonomy to implement strategy in the host market; specialised contributors are largely interdependent business units within the MNE, having less autonomy; world mandate subsidiaries are both locally responsive and globally integrated, having both operational and strategic autonomy (Birkinshaw and Morrison, 1995; Jarillo and Martínez, 1990). Subsidiaries that take on global strategies serve a number of markets and have high potential to offer country specific advantages to 
Table 1 . Subsidiary role typology.

\begin{tabular}{|c|c|c|c|}
\hline Key authors & $\begin{array}{l}\text { Local } \\
\text { implementer }\end{array}$ & Specialised contributor & World mandate \\
\hline White and Poynter (1984) & Miniature replica & $\begin{array}{l}\text { Rationalised manufacturer } \\
\text { Product specialist }\end{array}$ & Global mandate \\
\hline D’Cruz (1986) & Branch plant & Globally rationalized & $\begin{array}{l}\text { World product } \\
\text { mandate }\end{array}$ \\
\hline $\begin{array}{l}\text { Bartlett and Ghoshal } \\
\text { (1986) }\end{array}$ & Implementer & Contributor & Strategic leader \\
\hline $\begin{array}{l}\text { Jarillo and Martínez } \\
\qquad(1990)\end{array}$ & Autonomous & Receptive & Active \\
\hline $\begin{array}{l}\text { Gupta and Govindarajan } \\
\text { (1991) }\end{array}$ & $\begin{array}{l}\text { Local innovator } \\
\text { Implementer }\end{array}$ & Global innovator & Integrated player \\
\hline
\end{tabular}


the MNE (Rugman and Verbeke, 1992). Subsidiaries following a global strategy possess considerable resources, capabilities and expertise (Bartlett and Ghoshal, 1986) and are largely unconstrained by parent company controls on the scope of their activity (Birkinshaw and Morrison, 1995; White and Poynter, 1984).

The links between international activity (e.g. exports), local economy development and the host industry productivity are well established (Kneller and Pisu, 2007). Research evidence suggests that foreign-owned MNE subsidiaries frequently engage in international activities and may promote the international activity of the domestic firms (Blake and Pain, 2002; Wang et al., 2007). Subsidiaries reduce their production costs through utilisation of host country factor endowments (Njong, 2008). Foreign subsidiary international activities increase international market competitiveness in the host market which is responded by the domestic firms in the form of raising their international activity to protect their market share and earnings (Kneller and Pisu, 2007; Njong, 2008).

It is generally expected that subsidiaries are restricted to the roles assigned to them by the parent MNEs but there are two processes that generate some independence in subsidiary activity. First, greenfield subsidiaries are more likely to be constrained to the roles established by their parent than those that have previously operated independently or as part of differently owned group (Estrin et al., 2008). At the least, a period of time may lapse where an acquired subsidiary is integrated into the new owner's operations (Andersson and Forsgren, 1996; Harzing, 1999). Second, subsidiaries can take on strategies (initiatives) that reflect their own independent decision making (Birkinshaw and Pedersen, 2010; White and Poynter,1984). Initiatives can focus on either external (local or global) or the MNE's internal market or some combination of both (Birkinshaw, 1997). Initiative taking can be viewed as a dispersed form of corporate entrepreneurship that has the possibility of augmenting distinctive subsidiary capabilities, encouraging head office openness toward future subsidiary initiatives and of strengthening the subsidiary's credibility vis-à-vis the parent organisation (Birkinshaw, 1997, 1999). Global initiatives are most likely to be taken by subsidiaries with world mandates and those with distinctive resources and capabilities - as well, it has been observed that resources and capabilities developed in the local markets can be applied to meet the opportunities identified in the global markets (Birkinshaw, 1997).

Subsidiary decision making ability is influenced by the subsidiary management structures which may be hierarchical (centralised management) or heterarchical (decentralised management) (Dicken, 2007; Raziq and Perry, 2013). This suggests that roles and the management structures through which subsidiaries are controlled are linked in that a single reporting line gives more scope to tightly maintaining the activity of a subsidiary than does a heterarchical control structure. Management structures include direct management by the parent headquarters, management by regional headquarters/offices, networks/divisional headquarters, mandated offices, and also independent management by the subsidiary itself (Raziq and Perry, 2013). Subsidiaries under these structures operate under varying control levels, e.g. subsidiaries managed 
under regional headquarters are largely influenced (by their regional headquarters) in terms of developing their product, marketing and competitive strategies (Yeung et al., 2001), as opposed to other subsidiaries (e.g. managed independently) which generally do not require approvals for their operational and strategic decisions from headquarters.

Subsidiaries that are managed independently are able to pursue their own strategies, enhance their roles and have more chances to further develop than less autonomous subsidiaries (Venaik et al., 2005). Subsidiaries that are managed by networks of reporting channels are generally managed under divisional headquarters. Subsidiaries generally perform a range of activities i.e. discreet valueadded activities (e.g. development, training, manufacturing, and marketing facilities) for the MNE, and each of the subsidiary function generally reports to a separate division/unit (Forsgren et al., 1995). Under such structures where there are multiple units supervising activities of a single subsidiary, the decision making capacity within a subsidiary (among functions) is likely to differ.

\section{Subsidiary activity in New Zealand}

Foreign subsidiaries in New Zealand have depended much more upon offshore and particularly parent company resources than upon linkages with local firms (Scott-Kennel, 2001). This arises from the primary motive for foreign investment in New Zealand having been to access the local market (KPMG, 1995; Scott- Kennel, 2001). A secondary motive was to use New Zealand as an export base to access Australasian and Asian markets and as a manufacturing base to produce and sell products within and outside New Zealand but this was thought to be some- thing few subsidiaries did other than those engaged in the primary sector and involved in the export of mineral and agricultural commodities (Enderwick, 1995; KPMG, 1995; Scott-Kennel, 2001).

Regarding the overseas activity of subsidiaries a government survey of business operations in New Zealand estimates that more than half of all subsidiaries engage in imports, more than one-third but less than half of the subsidiaries engage in exports, less than a quarter engage in overseas production, and around one-third engage in collaboration with overseas organisations (Statistics-NZ, 2005-2011). The same survey shows few constraints on overseas activity, with exchange rate levels being the most likely (21\% of the subsidiaries) constraint on subsidiary international activity to be cited. Against some expectations (see Harzing and Noorderhaven, 2006; Mauro, 2000), potential constraints due to New Zealand's isolation and geographical remoteness (e.g. transportation costs) are not seen as major constraints by the majority of subsidiaries.

As for the global entrepreneurial activities of subsidiaries in New Zealand rather less empirical evidence exists, but some guidelines exist (from Statistics New Zealand data sources) on subsidiary activities including research and development and innovation. It is believed that engagement in research and development and innovation activity result in enhancement of subsidiary potential to take entrepreneurial initiatives (Birkinshaw, 1997). Statistics New Zealand data reveal that while overall a good percentage of foreign subsidiaries in New Zealand are involved in innovation (on average around $62 \%$ of subsidiaries), it is 
seen at low levels when individual innovation activity is analysed (see Appendix B). As for R\&D activity rather no data exists on the extent and nature of activity, but as a whole it is found that on average $15 \%$ of subsidiaries undertake R\&D activity.

\section{Conceptual Framework}

The major research question guiding this study is: "What if any, is the international role of foreign-owned subsidiaries in New Zealand?" To answer this question the study includes a number of secondary questions:

1. Based upon their international roles, what types of subsidiaries exist in New Zealand? 
2. What is the potential of foreign subsidiaries in New Zealand to take on international roles?

(a) What is the extent of autonomy exercised by subsidiaries, and what is the extent of parent resource support received by subsidiaries?

(b) To what extent are opportunities to use New Zealand as an export base recognized by the parent MNEs?

3. To what extent do subsidiaries have international roles?

(a) How important are local vs. international markets for subsidiaries?

(b) To what extent do subsidiaries take on global entrepreneurial initiatives?

4. How do subsidiary parent country of origin, types of investments, types of industry, and management structures affect subsidiary investment in international roles?

The study distinguishes two main types of international roles: exporting and entrepreneurial initiative. Exporting is conceived as simply selling the products/ services outside the host country (i.e. New Zealand) for example to regional/global markets. Entrepreneurial initiative taking is less easily defined than exporting. It can be seen as an (opportunistic) activity taken in response to a threat/opportunity seen in the focal (local, internal, global) market; an assigned activity by headquarters; or a planned activity by subsidiary - the purpose and expected outcome of all may be more than simply selling products/services. The study looks at only one type of initiative i.e. "global initiative", which is generally viewed as an entrepreneurial activity taken outside the host country.

The study includes a number of other factors that potentially influence the international roles e.g. subsidiary autonomy, parent resource support, parent MNE perceptions about New Zealand to be used for international activity, subsidiary home country, and subsidiary investment origins. The study also includes some key background concepts (e.g. motives of investment, industry type, and the management structure under which the subsidiary operates) all of which have relevance to the subsidiary international roles.

The study measures the extent of global market initiatives currently taken and/ or taken in the past. It is assumed that to take global initiative, subsidiaries require high levels of autonomy and parent resource support. Autonomy can be of two types operational and strategic, with strategic identified as policy decisions on "R\&D, product developments, and marketing" and operational to processes including production, sales, distribution and human resource management (McDonald et al., 2008). Autonomy is also needed for subsidiaries to take on export roles, and it has been found that autonomous subsidiaries have high 
propensity to export (McDonald et al., 2008). As for any initiative, subsidiaries require resource support and are largely dependent on parent firm resources literature suggests that subsidiaries in New Zealand largely draw on parent firm resources (Scott-Kennel, 2001), and though subsidiaries could get funding from external and domestic sources as well, majority get resources from parent firms (Dutton et al., 1999; Williams et al., 2008).

As for exports, the study focuses on the extent to which the subsidiaries currently serve non-New Zealand markets and the parent MNE perceptions about New Zealand as an export base. Influencing factors for driving exports include autonomy as it has been found that subsidiaries possessing high levels of autonomy actively engage in exporting of products/services (McDonald et al., 2011). Another influencing factor is subsidiary country of origin although a number of studies make contrasting claims as to whether country of origin affects the propensity to export (Fontagne and Pajot, 1997; Lipsey, 1991; O'Sullivan, 1993; Yamawaki, 2007). Other factors include the types of investment as it has been argued that acquired firms are more likely to be exporting than other firms (Estrin et al., 2008).

\section{Survey Design}

This study makes use of data from a survey of foreign-owned subsidiaries in New Zealand that was conducted from November 2011 to April 2012. The focus is on the survey data measuring subsidiary international activity and subsidiary characteristics that might be associated with differences in the activity undertaken. A summary of the questionnaire components drawn upon is provided in Appendix D.

The survey covered a sample of 952 wholly foreign-owned subsidiaries operating in New Zealand. The sample was obtained from Kompass New Zealand. Company Office New Zealand also maintains an official list of foreign-owned companies registered with them, but does not disclose postal addresses to public. The sampling frame therefore was mainly derived from the list provided by Kompass New Zealand supplemented by those from the Company Office list for which an internet address could be located.

The survey requested completion by the person who leads the subsidiary's foreign operations in New Zealand. In practice this included respondents with various designations including CEO, Country Manager, Managing Director, General Manager, COO, and the CFO. The survey was distributed by email and postal distribution depending on whether the Kompass database included an email address and whether the email request was responded to: respondents who did not 
respond to the email were sent postal surveys. The total responses received were 435 - six of the responses were partial therefore were deleted, leaving the total responses to 429 ; the final response rate is $45.06 \%$, which as identified by the comparable studies of multinational subsidiaries is well above the general response rate (see Harzing, 1997).

A number of tests are performed to check if the data is biased in terms of responses received, and the common method. Data is also checked for linearity/ normal distribution. As the data was obtained in more than one stage i.e. reminders had to be sent, a possibility of response bias may emerge, as the data may be dominated by responses, from respondents who were eager to respond, than those who were busy or reluctant. Extrapolation method is used to check for response bias (Armstrong and Overton, 1977; Pace, 1939) - mean scores of all the items (early responses vs. late responses) are compared to check for significant differences. No significant difference was found on any item, hence the data was deemed to be clear of any response bias.

As all the responses were received from a single respondent, a risk of common method bias exists. Harman single factor test is used to see if such a tendency occurs in the data exists - as per the method all the variables are loaded on to a single factor (under exploratory factor analysis) and checked that the total variance does not exceed 50\% (Harman, 1967). Results show a total variance of $14 \%$ hence clearing the data of any common method bias.

To test whether the data are normally distributed, Kolmogorov-Smirnov and Shapiro-Wilk tests are employed (Justel et al., 1997; Shapiro and Wilk, 1965) the tests showed that data is not normally distributed. Despite the growing argument that (under central limit theorem) large samples do not necessarily have to be checked for data normality (Lumley et al., 2002), in order to avoid any false positives, non-parametric equivalents e.g. Kruskal-Wallis analysis of variance (that do not assume data is normally distributed) test (instead of the traditional ANOVA) are employed (Kruskal and Wallis, 1952).

\section{Results and Discussion}

The results and discussion section is divided into four parts. The first part looks at the profile of subsidiaries in New Zealand and includes analysis on the key background concepts i.e. the subsidiary country of origin, entry mode and motives of investment. Part two presents the subsidiary potential for international roles and includes data analysis of a number of concepts that can be considered as precursors of international roles; they include subsidiary autonomy, parent resource support for subsidiaries, and perceptions to use New Zealand as an export base. Part three 
looks at the subsidiary actual participation in international roles and includes analysis on subsidiary roles and subsidiary entrepreneurial initiatives. Part four looks at how based on characteristics some groups of subsidiaries may emerge.

Profile of subsidiaries in New Zealand

Slightly over half the 429 responses are from subsidiaries with headquarters domiciled in Australia (112) and the United States (111). Subsidiaries from Japan (38), United Kingdom (37) and, Germany (31) are the next most important concentrations. By region, the largest share are European (130) followed by Oceania (117), North America (115), and Asia (67). Overall it is seen that subsidiaries involve investment from all parts of the world. Acquisitions (48\%) and greenfield operations (42\%) account for the majority of responses. Access to the local markets is the major (current) motive for multinationals to operate in New Zealand (Table 2).

\section{Subsidiary potential for international roles}

This section includes results summary of the influencing factors (including autonomy, parent resource support, and parent MNE perceptions about New Zealand as an export base) that drive subsidiary international roles.

\section{Subsidiary autonomy}

Subsidiaries have reasonable levels of autonomy for strategic and operational decisions (for distinctive measures see Appendix A) but tend to have more autonomy for decisions that are of operational nature than those that are of strategic nature (Table 3). Results indicate that on average, foreign subsidiaries in New Zealand possess operational autonomy to a major extent, and strategic autonomy at moderate extent. Autonomy may be high in some areas and low on others, and may vary from subsidiary to subsidiary based upon their roles and mandates e.g. subsidiaries that are chartered to serve a local market only may be highly locally autonomous and may have high levels of operational autonomy (but low levels of strategic autonomy Jarillo and Martínez, 1990), and subsidiaries that serve both global and local markets tend to have high levels of both operational and strategic autonomy (Birkinshaw and Morrison, 1995). New Zealand where subsidiaries are primarily built (more than two-third) to seek local markets only, and are heavily influenced (93\% of subsidiaries) by headquarters on long-term decisions (ScottKennel, 2001), are likely to be highly controlled by headquarters in terms of 
Table 2. Current motives to operate in New Zealand (frequency and percentage) .

\begin{tabular}{|c|c|c|c|c|c|c|c|c|c|c|}
\hline \multirow[b]{3}{*}{ Motives in New Zealand (429) } & \multicolumn{10}{|c|}{ Degree of influence } \\
\hline & \multicolumn{2}{|c|}{ None (1) } & \multicolumn{2}{|c|}{ Minor extent (2) } & \multicolumn{2}{|c|}{ Moderate extent (3) } & \multicolumn{2}{|c|}{ Major extent (4) } & \multicolumn{2}{|c|}{ Sole (5) } \\
\hline & $f$ & $\%$ & $f$ & $\%$ & $f$ & $\%$ & $f$ & $\%$ & $f$ & $\%$ \\
\hline Access to resources & 248 & 57.8 & 73 & 17 & 50 & 11.7 & 52 & 12.1 & 6 & 1.4 \\
\hline Access to the local market & 37 & 8.6 & 24 & 5.6 & 37 & 8.6 & 196 & 45.7 & 135 & 31.5 \\
\hline Access to technology, or R\&D activity & 269 & 62.7 & 98 & 22.8 & 37 & 8.6 & 22 & 5.1 & 3 & 0.7 \\
\hline Important customers are located in New Zealand & 103 & 24 & 57 & 13.3 & 74 & 17.2 & 152 & 35.4 & 43 & 10 \\
\hline Other & 406 & 94.6 & 0 & 0 & 0 & 0 & 17 & 4.0 & 6 & 1.4 \\
\hline
\end{tabular}


Table 3. Subsidiary autonomy (frequency, percentage, mean and SD).

\begin{tabular}{|c|c|c|c|c|c|c|c|c|c|c|c|c|}
\hline \multirow[b]{3}{*}{ Subsidiary autonomy $(n=429)$} & \multicolumn{10}{|c|}{ Degree of influence } & \multirow[b]{3}{*}{$\mu$} & \multirow[b]{3}{*}{ SD } \\
\hline & \multicolumn{2}{|c|}{ Not at all (1) } & \multicolumn{2}{|c|}{ Minor extent (2) } & \multicolumn{2}{|c|}{ Moderate extent (3) } & \multicolumn{2}{|c|}{ Major extent (4) } & \multicolumn{2}{|c|}{ Complete (5) } & & \\
\hline & $f$ & $\%$ & $f$ & $\%$ & $f$ & $\%$ & $f$ & $\%$ & $f$ & $\%$ & & \\
\hline Strategic autonomy & 3 & 0.7 & 48 & 11.2 & 161 & 37.5 & 180 & 42 & 37 & 8.6 & 3.47 & 0.83 \\
\hline Operational autonomy & 4 & 0.9 & 25 & 5.8 & 127 & 29.6 & 192 & 44.8 & 81 & 18.9 & 3.75 & 0.86 \\
\hline
\end{tabular}


activity, and so subsidiaries may possess high levels of operational autonomy while their strategic autonomy is low (Raziq et al., 2012, 2013).

\section{Parent resource support}

In the five years prior to the survey, 19.8\% (85) of subsidiaries sought parent resource support for global market initiatives of which $0.9 \%$ (4) were refused resource support, $10.3 \%$ (44) received partial resource support and only $8.4 \%$ (36) received full resource support. This indicates that while resource seeking from parents is low when requested some support is usually forthcoming.

\section{New Zealand as an export base}

Opportunities to use New Zealand as an export base are recognized to a "minor" or "moderate" by almost half the respondents (47.1\%). Analysis by industry (Primary Industries $(N 1 / 45 ; \mu 1 / 42: 8)$; Manufacturing $(N 1 / 4$ I87; $\mu$ 11/4 2:84); Services $(N 1 / 4237 ; \mu 1 / 42: 43)$ ) show that while opportunities to use New Zealand as an export base are recognized at almost the same extent (i.e. minor to moderate) among subsidiaries, significant differences (using Kruskal-Wallis test) are seen only between manufacturing sector and services sector industries $\left(H \frac{1}{4}\right.$ 5:492; $d f 1 / 4 \mathrm{I} ; p^{1 / 1 / 4}$ 0:0 I 9).

This shows that manufacturing sector industries are more likely to be exporting than service sectorindustries - this finding seems consistent with the general tendency for services sector subsidiaries to be less likely to export.

Examining the link between subsidiaries potential to take on export activity and their management hierarchies/heterarchies e.g. (parent control $\left(N \frac{1 / 4}{4} 44 ; \mu 1 / 42: 41\right.$ ); RHQ/offices $\left(N \frac{1}{4} 226 ; \mu 1 / 42: 48\right)$; mandated offices $\left(N \frac{1}{4}\right.$ I $8 ; \mu 1 / 42: 22$ ); network/DHQ control ( $N \frac{1}{4}$ I5; $\mu 1 \frac{1}{4}$ 2:93); independent control $\left(N \frac{1}{4}\right.$ I26; $\mu$ 1/4 2:94)) reveal the same extent (i.e. minor to moderate) of export opportunity. Significant differences however have been found among subsidiaries subsidiaries managed independently are more likely to use New Zealand as an export base than subsidiaries managed by parent headquarters $\left(H \frac{1 / 4}{4}\right.$ : 167 ; $d f 1 / 4$ I; $p 1 / 40: 04 I)$, and subsidiaries managed by RHQs/offices $(H 1 / 47: 488 ; d f 1 / 4$ I; $p 1 / 40: 006)$. A logical explanation of this can be that subsidiaries that are managed independently are more open in pursuing their perceived opportunities, and are less constrained than subsidiaries that are put under different hierarchies.

Subsidiary participation in international roles

\section{Markets served}

A third $(32.6 \%)$ of subsidiaries are engaged solely in serving the local market and over half $(54.5 \%)$ are predominantly engaged in serving the local market while a 
small number (3\%) have no involvement with the local market. The profile is almost revered with respect to serving international markets: close to a third $(30.5 \%)$ do not serve international markets at all — approximately $20 \%$ of the subsidiaries actively serve non-New Zealand markets while $18 \%$ take the international activity at moderate extents. Among the $20 \%$ that actively serve the international markets (slightly more than two thirds) also actively serve the local New Zealand markets. This suggests that slightly less than $15 \%$ of subsidiaries have broader roles in New Zealand, and may be considered as "active" subsidiaries (Birkinshaw and Morrison, 1995; Jarillo and Martínez, 1990).

An analysis of whether there are subsidiaries that serve local markets only or serve international markets only, indicates that there are eighty subsidiaries $(18.6 \%)$ that primarily serve the local market and do not serve any other markets, where as there are only seven subsidiaries $(1.6 \%)$ that primarily serve international markets and do not serve New Zealand local market (1.6\%). This shows that $80 \%$ of subsidiaries in New Zealand undertake more than one role - this indicates that roles of majority of subsidiaries in New Zealand are difficult to identify, if the expected/resultant role is only one role. These findings support the argument that subsidiary role is a complex phenomenon and subsidiaries do not necessarily have to have one role at a time, but can take multiple roles at any one time (Cavanagh and Freeman, 2012; Enright and Subramanian, 2007; Rugman et al., 2011).

The characteristics of subsidiaries that primarily serve the local market, primarily serve the international markets only, and predominantly serve the international markets are further explored (Table 4). Results show that more than half of subsidiaries that serve the local markets only are acquisitions and have fewer than 50 employees, majority owned by Australian based MNEs, managed by regional headquarters (with 26 based in Australia), and majority are services sector subsidiaries. Characteristics of subsidiaries that serve the international markets only show that majority of subsidiaries belong to manufacturing sector, are acquisitions and are managed independently. Characteristics of subsidiaries that predominantly serve the international markets show that majority of subsidiaries are manufacturing sector subsidiaries and have more than 50 employees.

Analysis by industry shows that subsidiaries belonging to the primary industry serve international markets at major extent $(\mu 1 / 43: 8)$, and manufacturing

$(\mu 1 / 42: 43)$ and services $(\mu 1 / 42: I I)$, at minor to moderate extents. Significant differences (using Kruskal-Wallis test) are seen among the subsidiaries — primary industry subsidiaries serve international markets more than both the manufacturing industry subsidiaries $(H 1 / 45: 640 ; d f 1 / 4 I ; p 1 / 40: 018)$, and services industry subsidiaries $\left(H 1 / 48: 009 ; d f 1 / 4 \mathrm{I} ; p^{1 / 4}\right.$ 0:005). Manufacturing industry subsidiaries serve international markets more than the services industry subsidiaries $\left(H^{1 / 1 / 4} 6: 665 ; d f 1 / 4 I ; p 1 / 40: 01\right)$. 
Table 4. Subsidiary characteristics (local only, international only, predominantly international).

\begin{tabular}{|c|c|c|c|c|c|c|}
\hline Subsidiary focus & Age & Industry & Size (employees) & Entry mode & Country of origin & Management structures \\
\hline \multirow[t]{5}{*}{ Local market only (80) } & $<5$ years: 8 & Manufacturing: 31 & $<50: 46$ & Greenfield: 27 & USA: 19 & Parent: 10 \\
\hline & 5-10 years: 9 & Services: 49 & $50-200: 20$ & Acquisition: 45 & Australia: 26 & RHQ/offices: 45 \\
\hline & 11-20 years: 15 & & 201-500:8 & Merger: 2 & Japan: 11 & Branch: 4 \\
\hline & $>20$ years: 48 & & 501-1000:2 & Joint Venture: 4 & European: 19 & Independent: 21 \\
\hline & & & $>1000: 4$ & Other: 2 & Asian: 5 & \\
\hline \multirow[t]{4}{*}{ Exports only (7) } & 5-10 years: 1 & Primary Industry: 1 & $<50: 3$ & Greenfield: 1 & USA: 1 & Parent: 1 \\
\hline & $11-20$ years: 2 & Manufacturing: 5 & $50-200: 1$ & Acquisition: 6 & Australia: 1 & RHQ/offires: 2 \\
\hline & $>20$ years: 4 & Services: 1 & 201-500:3 & & European: 3 & Independent: 4 \\
\hline & & & & & Asian: 2 & \\
\hline \multirow[t]{6}{*}{ Predominant exports - $20 \%$ (84) } & $<5$ years: 4 & Primary Industry: 4 & $<50: 41$ & Greenfield: 35 & USA: 16 & Parent: 7 \\
\hline & $5-10$ years: 11 & Manufacturing: 46 & 50-200: 24 & Acquisition: 38 & Australia: 13 & RHQ/offices: 34 \\
\hline & 11-20 years: 19 & Services: 34 & 201-500: 13 & Merger: 6 & Canada: 3 & Network: 5 \\
\hline & $>20$ years: 50 & & $501-1000: 4$ & Joint Venture: 5 & European: 28 & Independent: 38 \\
\hline & & & $>1000: 2$ & Franchise: 1 & Asian: 21 & \\
\hline & & & & Other: 4 & Oceania: 3 & \\
\hline
\end{tabular}


Analysis by management structures (parent control ( $\mu$ 1/4 2:23); RHQ/offices ( $\mu$ 1/4 2:2); mandated offices ( $\mu$ 1/4 I:72); network/DHQ control $(\mu 1 / 42: 47$ ); independent control $\left(\begin{array}{llll}\mu & 1 / 4 & 2: 52\end{array}\right)$ show that subsidiaries managed independently serve international markets more than subsidiaries managed by RHQs/offices $(H 1 / 44: 643 ; d f 1 / 4 I ; p 1 / 40: 03 I)$ and subsidiaries managed by mandated offices $(H 1 / 46: I 55 ; d f 1 / 4 I ; p 1 / 40: 013)$.

\section{Subsidiary initiative}

Almost half (47.8\%) of the subsidiaries have been involved in some form of global initiative in the five years prior to the survey - thought only $11 \%$ are actively involved in such initiatives. A major requirement for global market initiatives is high level of subsidiary strategic autonomy (Birkinshaw, 1997). While results (see Table 4) have shown that a good number of subsidiaries possess some form of strategic autonomy, the low number of subsidiaries that are actively involved in global initiatives indicate that subsidiaries may not have adequate strategic autonomy to undertake a global strategy. As serving the local New Zealand market is seen as the primary focus among subsidiaries, subsidiaries are likely to take a locally responsive strategy than a globally integrated strategy. The moderate to major levels of strategic autonomy (as indicted in this study, and as a characteristic of subsidiaries taking locally responsive strategy) is likely to be for serving the local markets only than for the global markets.

\section{Subsidiary international role by country of origin and entry mode}

There are six countries represented in the sample with 15 or more subsidiaries: Australia, United States, Germany, Japan, United Kingdom, and Switzerland. Using the Kruskal-Wallis analysis of variance test among the six countries: Australia $(N 1 / 4$ II $; \mu 1 / 42: 07)$, United States ( $N 1 / 4$ III; $\mu 1 / 42: 22)$, Germany $\left(N \frac{1}{4} 31 ; \mu 1 / 42: 16\right)$, Japan $\left(N \frac{1}{4} 38 ; \mu 1 / 42: 29\right)$, United Kingdom $(N 1 / 437 ; \mu 1 / 4$ 2:54), Switzerland $(N 1 / 4 \quad 15 ; \mu 1 / 42: 07)$ a significant difference is found between two subsidiary groups. Subsidiaries belonging to UK have a higher international role $\left(H \frac{1}{4} 4: 058\right.$; df $1 / 4$ I; $p 1 \frac{1}{4}$ 0:044) than subsidiaries belonging to Australia. Findings support the (one of the two opposing) claims about the subsidiary home country as factors influencing export capacities of subsidiaries - results find some support for the claim. Further analysis shows that both the country groups have an equal share of subsidiaries as per industry sectors (manufacturing versus services), have almost similar distributions of subsidiaries as per management structures, subsidiary age and subsidiary size - this shows that there may be some (external) country level characteristics that are influencing the international role, however such claims in this study are difficult to make. The two country groups slightly 
differ in motives. Both the number of subsidiaries and their mean scores (among UK based subsidiaries) are larger on seeking motives (resources, R\&D, technology) than Australian based subsidiaries which primarily have exploiting motives e.g. selling products - no significant differences among motives however are found. This may partly explain that a slight variation in motives may reflect the significant differences in international roles among the two country groups.

Results using the same test show no significant differences in international roles among subsidiaries based upon their investment origins (Greenfield $\left(N \frac{1}{4}\right.$ 174; $\left.\mu 1 \frac{1}{4} 2: 34\right)$; Acquisitions $\left(N \frac{1}{4} 202 ; \mu 1 / 42: 2\right)$ ). The findings goes inconsistent with the existing claim that suggests that acquired subsidiaries are more likely to export than others (see Estrin et al., 2008).

\section{Subsidiary autonomy and global initiative by industry and management structures}

Subsidiary level of autonomy and global initiatives are analysed as per industry and management structures. In order to check for statistically significant differences among groups, Kruskal-Wallis analysis of variance test is employed. As for subsidiary global initiative, some statistically significant differences among industry groups (Primary Industries ( $\mu 1 / 42: 4$ ); Manufacturing ( $\mu 1 / 42: 01$ ); Services

$(\mu 1 / 4 \mathrm{I}: 73)$ ) are found. Subsidiaries belonging to manufacturing industry sector $(H 1 / 46: 066 ; d f 1 / 4 I ; p 1 / 40: 014)$ show a higher incidence of global market initiative than subsidiaries belonging to service industry sector.

As per industry sectors, analysis of strategic autonomy (Primary Industries $(\mu$ 1/4 3:2); Manufacturing ( $\mu$ 1/4 3:5I); Services $(\mu$ 1/4 3:44)) and operational autonomy (Primary Industries ( $\mu$ 1/4 3:4); Manufacturing ( $\mu$ 1/4 3:83); Services $(\mu 1 / 43: 69)$ ) shows no significant differences, indicating that subsidiaries (as per industry) do not differ in terms of autonomy..

As per management structures (parent control ( $\mu 1 / 4 \mathrm{I}: 57$ ); RHQ/offices ( $\mu$ 1/4 I:72); mandated offices ( $\mu$ 1/4 I:72); network/DHQ control $(\mu 1 / 42: 2)$; independent control $\left(\begin{array}{lll}\mu & 1 / 4 & 2: 18\end{array}\right)$, results show some significant differences. Subsidiaries managed by network/DHQs show a higher $\left(H 1 / 45: 934 ; d f 1 / 4 I ; p^{1 / 4}\right.$ 0:015) incidence of global market initiative than subsidiaries managed by parent headquarters, and subsidiaries managed by RHQs/offices $\left(H \frac{1}{4} 4: 723 ; d f 1 / 4 I\right.$; $p 1 / 4$ 0:03). Subsidiaries managed independently show a higher incidence of global market initiatives than subsidiaries managed directly by parent companies $\left(H^{1 / 4} 10\right.$ : 750; $d f 1 / 4 \mathrm{I} ; \quad p 1 / 40: 0010)$, and subsidiaries managed by RHQs/offices $\left(H 1 / 4\right.$ I6:I23; df $1 / 4$ I; $p^{1 / 4}$ 0:000).

Analysis (as per management structures) of subsidiary strategic autonomy

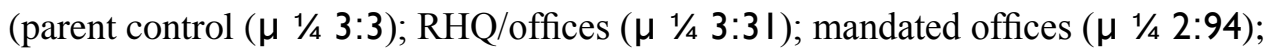


network/DHQ control ( $\left.\begin{array}{llll}\mu & 1 / 4 & 3: 27\end{array}\right)$; independent management ( $\left.\begin{array}{llll}\mu & 1 / 4 & 3: 9\end{array}\right)$, and subsidiary operational autonomy (parent control ( $\mu 1 / 43: 5$ ); RHQ/offices ( $\mu$ 1/4 3:6); mandated offices ( $\mu$ 1/4 3:17); network/DHQ control ( $\mu 1 / 4$ 3:67); independent $(\mu 1 / 44: 19))$ is made. Results show that subsidiaries managed independently have higher strategic autonomy $(H 1 / 4$ I5:673; $d f 1 / 4 I ; p 1 / 4 \quad 0: 000)$ and higher operational autonomy $\left(H \frac{1}{4} 22: 07 I ; d f^{1 / 4} I ; p 1 / 40: 000\right)$ than subsidiaries managed by parent headquarters; higher strategic autonomy $(H 1 / 442: 861$; df $1 / 4 \mathrm{I} ; p 1 / 40: 000)$ and higher operational autonomy $(H 1 / 438: 46 \mathrm{I} ; d f 1 / 4 \mathrm{I}$; $p 1 / 40: 000)$ than subsidiaries managed by RHQs/offices; higher strategic autonomy $\left(H \frac{1}{4}\right.$ 14:643; df $\left.1 / 4 \mathrm{I} ; p^{1 / 4} 0: 000\right)$ and higher operational autonomy $\left(H^{1 / 4}\right.$ 18: I98; $d f 1 / 4$ I; $p 1 \frac{1}{4}$ 0:000) than mandated offices; and higher strategic autonomy $(H 1 / 49: 066 ; d f 1 / 4 I ; p 1 / 40: 003)$ and higher operational autonomy $\left(H^{1 / 4} 6: 264 ; d f 1 / 4 I ; p^{1 / 4}\right.$ 0:0I2) than subsidiaries managed by a network/DHQs.

\section{Subsidiary groups}

The section reports a Two-step cluster analysis to examine whether subsidiaries can be classified according to their international roles (Table 5). Two groups of subsidiaries emerge with one having significantly higher scores than the other for all the variables studied including exports, strategic and operational autonomy, global initiative, global initiative resource support received and perceptions to use New Zealand as an export base. The results show that cluster 2 (36.8\% of subsidiaries) have higher mean scores than cluster 1 . An analysis of variance is conducted (using Kruskal-Wallis test) to check for the significant differences among the mean scores of groups to show how cluster membership are driven both the clusters are significantly different with subsidiaries in cluster 2 more active in exports and global initiatives, more autonomous, and receive more parent resource support than the subsidiaries in cluster 1 . The classification show that there are two types of subsidiaries in New Zealand with one having more opportunities to develop international role than the other. The two subsidiary groups can be classified as Constrained Subsidiaries (cluster 1), and Unconstrained Subsidiaries (cluster 2).

Subsidiary groups are further analysed by industry, country of origin, entry mode and reporting channels (see Appendix C). It is found that the majority (76\%) of the Constrained subsidiaries are managed by parent headquarters, regional headquarters/offices and mandated offices. This shows that majority of subsidiaries that are managed by parent headquarters, regional headquarters and branches have a lower export role, are less autonomous, and less entrepreneurial in global markets compared to other subsidiaries. 
Table 5. Subsidiary groups.

\begin{tabular}{lccc}
\hline & $\begin{array}{c}\text { Constrained } \\
\text { subsidiaries - } \\
\text { Cluster 1 (63.2\%) }\end{array}$ & $\begin{array}{c}\text { Unconstrained } \\
\text { subsidiaries - } \\
\text { Cluster 2 (36.8\%) }\end{array}$ & \\
\cline { 2 - 4 } Variables & $\mu$ & $\mu$ & p-value \\
\hline Serve markets outside New & 1.79 & 3.13 & 0.000 \\
$\quad$ Zealand & 3.2 & 3.92 & 0.000 \\
Strategic autonomy & 3.48 & 4.21 & 0.000 \\
$\begin{array}{l}\text { Operational autonomy } \\
\text { Global initiative }\end{array}$ & 1.28 & 2.85 & 0.000 \\
Global initiative - resource & 0.02 & 1.23 & 0.000 \\
$\quad$ support received & 2.39 & 2.99 & 0.002 \\
New Zealand as an export & & & \\
$\quad$ base & 271 & 158 & \\
Total & & & \\
\hline
\end{tabular}

Further analysis on Constrained subsidiaries show that majority (parent control: 72\%; RHQ control: 99\%; mandated office control: 93\%) of these subsidiaries are headquartered in the Asia Pacific region with majority (67\%) based in Australia. This shows that subsidiaries that have controlling offices in the region have relatively lesser propensity to take on international roles than others. It can be argued that controlling offices in the region either take, or allocate international roles to other locations of strategic importance while maintaining close control over subsidiary activity. It may also be argued that the existence of an office in the region with controlling mandates is associated with having multiple subsidiaries in the region and organisations have no need for intra-regional trade as they have operations in other locations or they select other places as their export base or both.

Overall the study results show that New Zealand subsidiaries are slightly different from subsidiaries of other developed countries in terms of knowledge seeking and dominant export oriented strategy of Greek subsidiaries (Manolopoulos, 2010) from Scotland and Ireland that mainly have specialised manufacturing roles (Delany, 1998; Tavares, 2002; Young et al., 2003), and from subsidiaries in overall United Kingdom that due to their global entrepreneurial orientation are being known as entrepreneurial subsidiaries (Boojihawon et al., 2007; Dutton et al., 1999). Subsidiaries in general are understood as having the tendency to evolve from as low as branch plants (Firn, 1975), to developmental subsidiaries (Young et al., 1994), and to the entrepreneurial subsidiaries (Dimitratos et al., 2009a,b). While New Zealand is a remote country and unlike other small developed countries does not enjoy proximity to other developed markets (including Europe and North America); it does however have proximity to other 
markets in the Asia Pacific region where subsidiaries can actively pursue entrepreneurial opportunities.

\section{Conclusions}

This exploratory study has five main conclusions. First, two types of subsidiaries are identified in New Zealand based upon their international engagement: Constrained and Unconstrained subsidiaries. These categories are unique to this study but contain aspects of subsidiary behaviour observed in other studies. For example, the Unconstrained subsidiary fits with the observation that subsidiaries with high levels of strategic autonomy are more likely to a have a global mandate than those with little autonomy. (Birkinshaw and Morrison, 1995), and a higher incidence of initiative taking along with higher levels of parent MNE resource support than the other subsidiaries. (Birkinshaw, 1999). Results have shown that subsidiaries managed by offices in the region in which subsidiaries operate have less potential and participation in international roles than subsidiaries managed independently, and managed by network/Divisional headquarters.

Second, a partial support to (one of the two contrasting claims) that whether the trade propensity of subsidiaries is related to the investor country of origin or not is found (see Fontagne and Pajot, 1997; Lipsey, 1991; O'Sullivan, 1993; Yamawaki, 2007). Findings (e.g. UK versus Australian subsidiaries in the study) suggest a relation exists - this is seen mainly as a reflection of different motives of investments that may be common among MNEs within in a particular country and/ or different among a number of countries. It is asserted that MNEs of different countries of origin tend to see benefits in the host country that may be unique to their country e.g. New Zealand benefits may be unique to UK, but not to Australia (due to the geographical location that the two countries i.e. Australia and New Zealand, share). No differences among subsidiaries based upon their investment origins/entry mode however found. It is therefore concluded that international activities including serving international markets, exports, etc. are not related to subsidiary investments origins.

Third, subsidiaries affiliated to the primary sector are more likely to develop international roles than are subsidiaries affiliated to other sectors. New Zealand is a predominantly land-based economy with a high dependence on agriculture, fishing and forestry as sources of overseas income with many of the country's largest enterprises linked to these parts of the economy. Previous studies have established that subsidiaries operating in a dynamic environment are more likely to develop broad roles than are those in stable activities (Verbeke et al., 2007). On the basis that the primary sector is the most dynamic component of the New Zealand 
economy, the study's finding is consistent with this broader argument. Manufacturing industry subsidiaries are more likely to export, serve international markets, and be globally entrepreneurial than subsidiaries that belong to the services industry. This finding has implications for manufacturing subsidiaries in New Zealand - subsidiaries that take on internal market initiatives seek (from parent MNE) for development (e.g. R\&D, manufacturing) facilities to be moved to their operations. Such facilities provide opportunities for subsidiaries to increase their value-added contributory role, develop and form centers of excellence (Birkinshaw, 1996; Birkinshaw et al., 1998).

Fourth, the management structure under which the subsidiary operates is an indicator of the roles performed by a subsidiary. This study found that subsidiaries that are managed independently tend to be more likely to export and undertake initiatives with global application than are subsidiaries managed by the parent headquarters or by a regional headquarters. Similarly, subsidiaries managed independently tend to have higher strategic and operational autonomy than subsidiaries under any of the other forms of management structure identified in the study. Participation in initiatives with global application is found to increase where the subsidiary is managed by a network of relationships or by a divisional headquarters than where the subsidiary is managed by the parent headquarters or by a regional headquarters. These findings indicate the importance of giving greater attention to the management structure through which a subsidiary is controlled than has tended to be given previously.

Fifth, findings indicate that the overall roles of a subsidiary are a complex phenomenon and may not be accurately determined with the assumption that subsidiaries play only one role at a time - this conclusion supports the theoretical claim that existing subsidiary role typologies are overly simplistic and generic in their assumptions (Enright and Subramanian, 2007). More than three quarters of subsidiaries in New Zealand take on a number of different roles (at varying extents) at one time, and while serving the local market is dominated as the primary role, this may not reflect a number of other roles (as so the overall role) that subsidiaries take or may take in future.

Finally, the overall importance of this exploratory study is the discovery that a wide variety of foreign-owned subsidiaries in New Zealand take on some form of international role. This contrasts with a tendency to assume that because subsidiaries in New Zealand are established principally to serve the local market this precludes them taking on broader responsibilities for the parent organisation. This happens because subsidiaries even when serving the local market have a tendency to acquire specialised resources and distinctive capabilities that help them further the role of their subsidiary. To be clear the international role that is developed may still account for a small share of the subsidiary's total activity but it 
does mean an additional growth path is opened up for the subsidiary. Awareness of this potential has significant implications for New Zealand policy makers concerned with the control or promotion of inward foreign direct investment. It suggests that the benefits of foreign investment may be underestimated by the lack of recognition of the way that a local market focus does not preclude subsidiaries developing international roles. This has potential to considerably increase the case for encouraging foreign investment. A first step toward achieving this is to gather further insight into the developing international roles of foreign-owned companies and to provide information on exemplar internalised subsidiaries as a way of demonstrating the feasibility of allocating international roles to subsidiaries in New Zealand.

\section{Appendices}

Appendix A. Autonomy (strategic and operational)

\begin{tabular}{lcc}
\hline Subsidiary autonomy & Factor loadings & $\begin{array}{c}\text { Reliability } \\
\text { analysis }\end{array}$ \\
\hline $\begin{array}{l}\text { Strategic autonomy } \\
\text { Hiring senior personnel }\end{array}$ & 0.832 \\
Outsourcing production/services & 0.713 & \\
New market development & 0.762 & \\
New product development & 0.637 & \\
Annual budget setting & 0.641 & \\
Changes in the organization of activity & 0.704 & \\
$\quad$ in New Zealand & 0.678 & \\
Financing (debt/equity) & & \\
Choice of technology & 0.660 & \\
Operational autonomy & 0.669 & \\
Changes in standard operating & & \\
$\quad$ procedures & 0.865 & \\
Changes in product/service design & 0.776 \\
Day to day management & 0.721 &
\end{tabular}


Appendix B. Activities supporting innovation

\begin{tabular}{|c|c|c|c|c|c|}
\hline \multirow[b]{2}{*}{ Activity } & \multicolumn{5}{|c|}{ Percentage of subsidiaries } \\
\hline & $\begin{array}{c}2005 \\
\%\end{array}$ & $\begin{array}{c}2007 \\
\%\end{array}$ & $\begin{array}{c}2009 \\
\%\end{array}$ & $\begin{array}{c}2011 \\
\%\end{array}$ & $\begin{array}{c}\text { Average } \\
\%\end{array}$ \\
\hline Acquired machinery and equipment & 28 & 15 & 21 & 13 & 19 \\
\hline Acquired computer hardware and software & 52 & 24 & 21 & 19 & 29 \\
\hline Acquired other knowledge & 18 & 11 & 12 & 9 & 13 \\
\hline $\begin{array}{l}\text { Implemented new business strategies or management } \\
\text { techniques }\end{array}$ & 41 & 21 & 20 & 15 & 24 \\
\hline Organisational restructure & 39 & 13 & 12 & 10 & 19 \\
\hline Design (e.g. industrial, graphic or fashion design) & 18 & 11 & 12 & 12 & 13 \\
\hline Marketed the introduction of new goods or services & 37 & 29 & 21 & 23 & 28 \\
\hline Market research & 33 & 18 & 15 & 14 & 20 \\
\hline Significant changes to marketing strategies & 24 & 12 & 12 & 7 & 14 \\
\hline Employee training & 57 & 33 & 26 & 23 & 35 \\
\hline
\end{tabular}

Appendix C. Characteristics of subsidiary groups

\begin{tabular}{|c|c|c|c|c|}
\hline $\begin{array}{l}\text { Subsidiary } \\
\text { clusters }\end{array}$ & Industry & Entry mode & Country of origin & $\begin{array}{c}\text { Management } \\
\text { structures }\end{array}$ \\
\hline \multirow{6}{*}{$\begin{array}{l}\text { Constrained } \\
\text { subsidiaries }\end{array}$} & Primary Industry: 2 & Greenfield: 115 & USA: 77 & Parent: 32 (73\%) \\
\hline & Manufacturing: 108 & Acquisition: 125 & Australia: 76 & RHQ: $159(70 \%)$ \\
\hline & Services: 161 & Merger: 10 & UK: 14 & $\begin{array}{c}\text { Mandated Office: } \\
15(83 \%)\end{array}$ \\
\hline & & Franchise: 3 & Germany: 22 & Network: $7(47 \%)$ \\
\hline & & Joint Venture: 12 & Japan: 23 & $\begin{array}{l}\text { Independent: } 58 \\
\qquad(46 \%)\end{array}$ \\
\hline & & Other: 6 & $\begin{array}{l}\text { Switzerland } 13 \\
\text { Other: } 46\end{array}$ & \\
\hline \multirow{5}{*}{$\begin{array}{r}\text { Unconstrained } \\
\text { subsidiaries }\end{array}$} & Primary Industry: 3 & Greenfield: 62 & USA: 34 & Parent: $12(27 \%)$ \\
\hline & Manufacturing: 82 & Acquisition: 79 & Australia: 36 & RHQ: 67 (30\%) \\
\hline & Services: 72 & Merger: 5 & UK: 23 & $\begin{array}{c}\text { Mandated Office: } \\
03(17 \%)\end{array}$ \\
\hline & Franchise: 1 & Japan:15 & Network: 08 (53\%) & \\
\hline & $\begin{array}{l}\text { Joint Venture: } 8 \\
\text { Other: } 3\end{array}$ & Other: 50 & Independent: 68 (54\%) & \\
\hline
\end{tabular}


Appendix D. Research questions and measurement

\begin{tabular}{|c|c|c|c|}
\hline & esearch question & Measurement & Source/Influence \\
\hline 1 & $\begin{array}{l}\text { Subsidiary potential to } \\
\text { take on international } \\
\text { roles }\end{array}$ & $\begin{array}{l}\text { Autonomy (strategic and } \\
\text { operational autonomy in } \\
\text { Appendix A): On a scale of } \\
\text { 1-5, what level of decision } \\
\text { making authority do New } \\
\text { Zealand subsidiaries have? } \\
\text { Export Base: On a scale of } \\
\text { 1-4, to what extent opportu- } \\
\text { nities to use New Zealand as } \\
\text { an export base are recognised } \\
\text { by the parent MNEs? } \\
\text { Resource Support Recieved } \\
\text { (for): Developing new pro- } \\
\text { ducts/services in New Zealand } \\
\text { to be sold internationally } \\
\text { (N/A (0), None (1), Partial (2), } \\
\text { Full (3)) }\end{array}$ & $\begin{array}{l}\text { (Ambos et al., 2010; Ambos and } \\
\text { Birkinshaw, 2010; } \\
\text { Birkinshaw et al., 1998; } \\
\text { Borini } \text { et al., 2009; } \\
\text { Enderwick, 1995; } \\
\text { Gammelgaard } \text { et al., 2012; } \\
\text { Raziq et al., 2012; Raziq and } \\
\text { Perry, 2012b) }\end{array}$ \\
\hline 2 & $\begin{array}{l}\text { How are the current } \\
\text { motives of foreign } \\
\text { multinationals to } \\
\text { operate in New } \\
\text { Zealand explained? }\end{array}$ & See Table 2 & $\begin{array}{l}\text { (KPMG, 1995; Scott-Kennel, } \\
\text { 2001) }\end{array}$ \\
\hline 3 & $\begin{array}{l}\text { To what extent is the } \\
\text { international role } \\
\text { related to subsidiary } \\
\text { country of origin, type } \\
\text { of investment, } \\
\text { industry, and } \\
\text { management } \\
\text { structures? }\end{array}$ & - & $\begin{array}{l}\text { (Estrin et al., 2008; Fontagne and } \\
\text { Pajot, 1997; Lipsey, 1991; } \\
\text { O'Sullivan, 1993; Raziq and } \\
\text { Perry, 2013; Yamawaki, } \\
\text { 2007) }\end{array}$ \\
\hline 4 & $\begin{array}{l}\text { What is the extent of } \\
\text { international role taken } \\
\text { by subsidiaries? }\end{array}$ & $\begin{array}{l}\text { Local Market: On a scale of 1- } \\
\text { 5, to what extent New Zealand } \\
\text { subsidiaries serve New Zeal- } \\
\text { and market. } \\
\text { International Market: On a } \\
\text { scale of 1-5, to what extent } \\
\text { New Zealand subsidiaries } \\
\text { serve markets outside of New } \\
\text { Zealand. } \\
\text { Global Initiative: On a scale of } \\
\text { 1-4, in the past } 5 \text { years, to }\end{array}$ & $\begin{array}{l}\text { (Birkinshaw et al., 1998; Borini } \\
\text { et al., 2009; Raziq et al., } \\
\text { 2012, 2013; Raziq and Perry, } \\
\text { 2012b) }\end{array}$ \\
\hline
\end{tabular}


Appendix D (Continued)

\begin{tabular}{ll}
\hline Research question & \multicolumn{1}{c}{ Measurement } \\
\hline & Source/Influence what extent New Zealand \\
subsidiaries developed new \\
products/services in New \\
Zealand to be sold interna- \\
tionally? \\
\hline
\end{tabular}

\section{References}

Ambos, TC, U Andersson and JM Birkinshaw (2010). What are the consequences of initiative-taking in multinational subsidiaries? Journal of International Business Studies, 41(7), 1099-1118.

Ambos, TC and JM Birkinshaw (2010). Headquarters' attention and its effect on subsidiary performance. Management International Review, 50(4), 449-469.

Andersson, U and M Forsgren (1996). Subsidiary embeddedness and control in the multinational corporation. International Business Review, 5(5), 487-508.

Andersson, U, M Forsgren and U. Holm (2007). Balancing subsidiary influence in the federative MNC: A business network view. Journal of International Business Studies, 38(5), 802-818.

Armstrong, JS and TS Overton (1977). Estimating nonresponse bias in mail surveys. Journal of Marketing Research, 16(August), 396-402.

Bartlett, CA and S Ghoshal (1986). Tap your subsidiaries for global reach. Harvard Business Review, 64(6), 87-94.

Birkinshaw, JM (1996). How multinational subsidiary mandates are gained and lost. Journal of International Business Studies, 27(3), 467-495.

Birkinshaw, JM (1997). Entrepreneurship in multinational corporations: The characteristics of subsidiary initiatives. Strategic Management Journal, 18(3), 207-229.

Birkinshaw, JM (1999). The determinants and consequences of subsidiary initiative in multinational corporations. Entrepreneurship Theory and Practice, 24(1), 9-36.

Birkinshaw, JM and N Hood (1997). An empirical study of development processes in foreign-owned subsidiaries in Canada and Scotland. MIR: Management International Review, 37(4), 339-364.

Birkinshaw, JM, N Hood and S Jonsson (1998). Building firm-specific advantages in multinational corporations: The role of subsidiary initiative. Strategic Management Journal, 19(3), 221-241.

Birkinshaw, JM and AJ Morrison (1995). Configurations of strategy and structure in subsidiaries of multinational corporations. Journal of International Business Studies, 26(4), 729-753. 
Birkinshaw, JM and T Pedersen (2010). Strategy and management in MNE subsidiaries. In The Oxford handbook of international business AM Rugman (Ed.), 2nd edn. Oxford, UK: Oxford University Press.

Blake, AP and N Pain (2002). Investigating structural changes in UK export performance: The role of innovation and direct investment. NIESR Discussion Papers. National Institute of Economic and Social Research. Retrieved from http://EconPapers.repec. org/RePEc:nsr:niesrd:71.

Boojihawon, DK, P Dimitratos and S Young (2007). Characteristics and influences of multinational subsidiary entrepreneurial culture: The case of the advertising sector. International Business Review, 16(5), 549-572.

Borini, FM, MTL Fleury, ACC Fleury and MDMO Junior (2009). The relevance of subsidiary initiatives for Brazilian multinationals. RAE-revista de administração de empresas, 49(3), 253-265.

Cavanagh, A and S Freeman (2012). The development of subsidiary roles in the motor vehicle manufacturing industry. International Business Review, 21(4), 602617.

Delany, E (1998). Strategic development of multinational subsidiaries in Ireland. In Multinational Corporate Evolution and Subsidiary Development JM Birkinshaw and N Hood (Eds.), pp. 239-267. London: Macmillan.

Dicken, P (2007). Global Shift: Mapping the Changing Contours of the World Economy. New York: Guilford.

Dimitratos, P, I Liouka and S Young (2009a). Regional location of multinational corporation subsidiaries and economic development contribution: Evidence from the UK. Journal of World Business, 44(2), 180-191.

Dimitratos, P, L Liouka, D Ross and S Young (2009b). The multinational enterprise and subsidiary evolution: Scotland since 1945. Business History, 51(3), 401-425.

Dutton, JE, SJ Ashford, RM O'Neill, E Hayes and EE Wierba (1999). Reading the wind: How middle managers assess the context for selling issues to top managers. IEEE Engineering Management Review, 27(2), 79-92.

Enderwick, P (1995). The Contribution of Foreign Direct Investment to the New Zealand Economy. Auckland, NZ: American Chamber of Commerce in New Zealand.

Enright, MJ and V Subramanian (2007). An organizing framework for mnc subsidiary typologies. Management International Review, 47(6), 895-924.

Estrin, S, KE Meyer, M Wright and F Foliano (2008). Export propensity and intensity of subsidiaries in emerging economies. International Business Review, 17(5), 574586.

Firn, JR (1975). External control and regional policy. In The Red paper on Scotland G. Brown (Ed.), pp. 153-169. Edinburgh: EUSPB.

Fontagne, L and M Pajot (1997). How Foreign Direct Investment Affects International Trade and Competitiveness: An Empirical Assessment. CEPII research center. Retrieved from http://ideas.repec.org/p/cii/cepidt/1997-17.html. 
Forsgren, M, U Holm and J Johanson (1995). Division headquarters go abroad — A step in the internationalization of the multinational corporation. Journal of Management Studies, 32(4), 475-491, doi: 10.1111/j.1467-6486.1995.tb00785.x.

Gammelgaard, J, F McDonald, A Stephan, H Tüselmann and C Dörrenbächer (2012). The impact of increases in subsidiary autonomy and network relationships on performance. International Business Review, 21(6), 1158-1172.

Harman, H (1967). Modern Factor Analysis. Chicago, IL: University of Chicago Press.

Harzing, AWK (1997). Response rates in international mail surveys: Results of a 22 country study. International Business Review, 6(6), 641-665.

Harzing, AWK (1999). Managing the Multinationals: An International Study of Control Mechanisms. Northampton, UK: Edward Elgar.

Harzing, AWK and N Noorderhaven (2006). Geographical distance and the role and management of subsidiaries: The case of subsidiaries down-under. Asia Pacific Journal of Management, 23(2), 167-185.

Jarillo, JC and JI Martínez (1990). Different roles for subsidiaries: The case of multinational corporations in Spain. Strategic Management Journal, 11(7), 501-512.

Johanson, J and J-E Vahlne (1977). The internationalization process of the firm - A model of knowledge development and increasing foreign market commitments. Journal of International Business Studies, 8, 23-32.

Justel, A, D Peña and R Zamar (1997). A multivariate Kolmogorov-Smirnov test of goodness of fit. Statistics \& Probability Letters, 35(3), 251-259.

Kneller, R and M Pisu (2007). Industrial linkages and export spillovers from FDI. World Economy, 30(1), 105-134.

KPMG (1995). Foreign Ownership - Cause for Concern. Wellington: KPMG.

Kruskal, WH and WA Wallis (1952). Use of ranks in one-criterion variance analysis. Journal of the American Statistical Association, 47(260), 583-621.

Lipsey, RE (1991). Foreign direct investment in the United States and U.S. trade. The ANNALS of the American Academy of Political and Social Science, 516(1), 76-90 doi: 10.1177/0002716291516001007

Lumley, T, P Diehr, S Emerson and L Chen (2002). The importance of the normality assumption in large public health data sets. Annual Review of Public Health, 23, 151169.

Manolopoulos, D (2010). Roles of foreign-owned subsidiaries in a European peripheral economy. Management Research Review, 33(8), 840-859.

Mauro, FD (2000). The Impact of Economic Integration on FDI and Exports: A Gravity Approach. Brussels, BE: Centre for European Policy Studies.

McDonald, F, S Warhurst and M Allen (2008). Autonomy, Embeddedness, and the performance of foreign owned subsidiaries. Multinational Business Review, 16(3), 73-92. McDonald, F, HJ Tüselmann, S Voronkova and S Golesorkhi (2011). The strategic development of subsidiaries in regional trade blocs. Multinational Business Review, 19(3), 256-271. 
Njong, AM (2008). Investigating the Effects of Foreign Direct Isnvestment on Export Growth in Cameroon. Paper presented at the UNECA Ad-hoc Expert Group Meeting in Addis Ababa, Ethiopia.

O'Sullivan, PJ (1993). An assessment of Ireland's export-led growth strategy via foreign direct investment: 1960-1980. Weltwirtschaftliches Archiv, 129(1), 139-158.

OECD (2009). OECD Economic Surveys: New Zealand 2009. OECD.

OECD (2011). OECD Economic Surveys: New Zealand 2011. OECD.

Pace, CR (1939). Factors influencing questionnaire returns from former university students. Journal of Applied Psychology, 23(3), 388-397.

Pike, A (1998). Making performance plants from branch plants? In-situ restructuring in the automotive industry in UK Region. Environment and Planning A (30), 881900.

Pike, A, A Rodríguez-Pose and J Tomaney (2007). What kind of local and regional development and for whom? Regional Studies, 41(9), 1253-1269.

Raziq, MM, FM Borini and M Perry (2012). Subsidiary initiatives and subsidiary autonomy: Evidence from New Zealand and Brazil. International Entrepreneurship and Management Journal, 1-17, doi: 10.1007/s11365-012-0240-5

Raziq, MM, FM Borini, M Perry and M Battisti (2013). Subsidiary characteristics and impact on subsidiary strategic and operational autonomy. Journal of Transnational Management, 18(3), 219-241, doi: 10.1080/15475778.2013.817271

Raziq, MM and M. Perry (2012a). Foreign direct investment in New Zealand: Does it justify negative assessment? Regional Science Policy \& Practice, 4(2), 155-164.

Raziq, MM and Perry, M. (2012b). Foreign direct investment in New Zealand: The subsidiary-management perspective. Proceedings of the British Academy of Management 2012 Conference.

Raziq, MM and M Perry (2013). A conceptual model of foreign subsidiary strategy and management: The case of New Zealand. Journal of Applied Management and Entrepreneurship, 18(3), 3-24.

Rosenberg, B (1998). Foreign investment in New Zealand: The current position. In P. Enderwick (Ed.), Foreign Investment: The New Zealand Experience. Auckland, NZ: Dunmore.

Rugman, AM and A Verbeke (1992). A note on the transnational solution and the transaction cost theory of multinational strategic management. Journal of International Business Studies, 23(4).

Rugman, AM, A Verbeke and W Yuan (2011). Re-conceptualizing Bartlett and Ghoshal's classification of national subsidiary roles in the multinational enterprise. Journal of Management Studies, 48(2), 253-277.

Scott-Kennel, J (2001). The Impact of Foreign Direct Investment on New Zealand Industry. University of Waikato.

Scott-Kennel, J (2007). Foreign direct investment and local linkages: An empirical investigation. Management International Review, 47(1), 51-77.

Shapiro, SS and MB Wilk (1965). An analysis of variance test for normality (complete samples). Biometrika, 52(3), 591-611. 
Statistics-NZ (2005-2011). Business Operations Surveys. Wellington, NZ: Statistics New Zealand.

Tavares, AT (2002). Multinational subsidiary evolution and public policy: Two tales from the European periphery. Journal of Industry, Competition and Trade, 2(3), 195213.

Venaik, S, DF Midgley and TM Devinney (2005). Dual paths to performance: The impact of global pressures on MNC subsidiary conduct and performance. Journal of International Business Studies, 36(6), 655-675.

Verbeke, A, JJ Chrisman and W Yuan (2007). A note on strategic renewal and corporate venturing in the subsidiaries of multinational enterprises. Entrepreneurship Theory and Practice, 31(4), 585-600.

Wang, C, PJ Buckley, J Clegg and M Kafouros (2007). The impact of inward foreign direct investment on the nature and intensity of Chinese manufacturing exports. Transnational Corporations, 16(2).

White, RE and TA Poynter (1984). Strategies for foreign-owned subsidiaries in Canada. Business Quarterly, 48(4), 59-69.

Williams, D, F McDonald, HJ Tüselmann and C Turner (2008). Domestic sourcing by foreign-owned subsidiaries. Environment and Planning C: Government and Policy, 26(1), 260-276.

Yamawaki, H (2007). Japanese Exports and Foreign Direct Investment: Imperfect Competition in International Markets. New York: Cambridge University Press.

Yeung, HW, J Poon and M Perry (2001). Towards a regional strategy: The role of regional headquarters of foreign firms in singapore. Urban Studies, 38(1), 157-183.

Young, S, N Hood and S Dunlop (2003). Global strategies, multinational subsidiary roles and economic impact in Scotland. In The Multinational Subsidiary: Management, Economic Development and Public Policy, N Hood (Ed.), pp. 125-146. New York: Palgrave Macmillan.

Young, S, N Hood and E Peters (1994). Multinational enterprises and regional economic development. Regional Studies, 28(7), 657-677. 